\title{
Etiopathogenesis of Recurrent Aphthous Stomatitis and the Role of Immunologic Aspects: Literature Review
}

\author{
Zuzanna Ślebioda $\cdot$ Elżbieta Szponar • \\ Anna Kowalska
}

Received: 31 May 2013/Accepted: 28 October 2013/Published online: 12 November 2013

(C) The Author(s) 2013. This article is published with open access at Springerlink.com

\begin{abstract}
Recurrent aphthous stomatitis (RAS; recurrent aphthous ulcers; canker sores) belongs to the group of chronic, inflammatory, ulcerative diseases of the oral mucosa. Up to now, the etiopathogenesis of this condition remains unclear; it is, however, considered to be multifactorial. The results of currently performed studies indicate that genetically mediated disturbances of the innate and acquired immunity play an important role in the disease development. Factors that modify the immunologic response in RAS include: food allergies, vitamin and microelement deficiencies, hormonal and gastrointestinal disorders (e.g., celiac disease, Crohn's disease, ulcerative colitis), some viral and bacterial infections, mechanical injuries and stress. In this paper, we presented the main etiopathogenetic factors of RAS with a special emphasis on the mechanisms of the immune response modification. Moreover, we discussed the crucial clinical symptoms and types of RAS together with epidemiologic data based on the current medical literature reports and our own observations.
\end{abstract}

Keywords Recurrent aphthous stomatitis . Etiopathogenesis · Immunologic factors · Cytokines

Z. Ślebioda $(\varangle) \cdot$ E. Szponar

Department of Oral Mucosa Diseases, University of Medical

Sciences, Bukowska 70, 60-812 Poznan, Poland

e-mail: zuzia_slebioda@o2.pl

A. Kowalska

Institute of Human Genetics in Poznan, Polish Academy

of Sciences, Poznan, Poland

A. Kowalska

Division Biology of Civilization Diseases, Department of Chemistry and Clinical Biochemistry, University of Medical Sciences, Poznan, Poland

\section{Introduction}

Recurrent aphthous stomatitis (RAS; recurrent aphthous ulcers; canker sores) belongs to the group of chronic, inflammatory diseases of the oral mucosa (Field and Allan 2003; McCullough et al. 2007; Rogers 1997; Scully and Porter 2008). The most characteristic symptom of the disease is the recurrent onset of single or multiple painful erosions and ulcers that appear mainly on unattached oral mucosa of the lips, cheeks and tongue. Occasionally the lesions may also be observed on strongly keratinized palatal and gingival mucosa. The eruptions are surrounded by a characteristic erythematous halo and covered with fibrous coating (Chavan et al. 2012; Rogers 1997). Considering the clinical features, three main types of recurrent aphthae can be distinguished: minor aphthae (Mikulicz's aphthae; MiRAS), major aphthae (Sutton's aphthae; MaRAS) and herpetiform aphthae (HeRAS) (Burruano and Tortorici 2000; Chattopadhyay and Chatterjee 2007; Natah et al. 2004; Tappuni et al. 2013; Woo and Sonis 1996). The comparison of the most crucial clinical features of RAS according to their classification is presented in Table 1.

Recurrent aphthae appearing simultaneously on the oral and genital mucosa are one of the symptoms of Behçet's syndrome, a systemic, inflammatory disease with a suspected autoimmune background (Freysdottir et al. 1999; Lehner 1978; Williams and Lehner 1977).

The prevalence of RAS in the general population ranges between 5 and $25 \%$. Such significant differences have been reported depending on the origin of the examined groups and populations as well as on the studies' design and methodology (Liang and Neoh 2012; Rogers 1997; Scully et al. 2003; Shashy and Ridley 2000). The presence of aphthae directly during the clinical examination is detected in a lower percentage of the examined subjects 
Table 1 Clinical characteristic of RAS according to their classification

\begin{tabular}{|c|c|c|c|c|c|c|c|c|}
\hline \multirow{2}{*}{$\begin{array}{l}\text { Type of } \\
\text { RAS }\end{array}$} & \multicolumn{8}{|c|}{ Clinical feature } \\
\hline & $\begin{array}{l}\text { Size } \\
(\varnothing \mathrm{mm})\end{array}$ & $\begin{array}{l}\text { Type and } \\
\text { number of } \\
\text { lesions }\end{array}$ & Depth & Scar & $\begin{array}{l}\text { Duration } \\
\text { (days) }\end{array}$ & $\begin{array}{l}\text { Peek onset } \\
\text { (age) }\end{array}$ & $\begin{array}{l}\text { Frequency compared to } \\
\text { other RAS types }(\%)\end{array}$ & Localization \\
\hline MiRAS & $5-10$ & $<10$ & Shallow & No & $10-14$ & $\begin{array}{l}2 \text { life } \\
\text { decade }\end{array}$ & $75-90$ & $\begin{array}{l}\text { Non-keratinized oral mucosa. Often: lips, } \\
\text { buccal regions, tongue margins }\end{array}$ \\
\hline MaRAS & $>10$ & $1-3$ & Deep & Yes & $>14$ & $\begin{array}{l}1 \text { and } 2 \text { life } \\
\text { decade }\end{array}$ & $10-15$ & $\begin{array}{l}\text { Keratinized and non-keratinized oral } \\
\text { mucosa. Often: soft palate }\end{array}$ \\
\hline HeRAS & $<5$ & $>10$ & Shallow & No & $10-14$ & $\begin{array}{l}3 \text { life } \\
\text { decade }\end{array}$ & $5-10$ & $\begin{array}{l}\text { Non-keratinized oral mucosa. Often: floor } \\
\text { of the mouth, ventral surface of the } \\
\text { tongue }\end{array}$ \\
\hline
\end{tabular}

Table 2 RAS prevalence in the clinical examination and based on the patient's history in the literature reports

\begin{tabular}{|c|c|c|c|c|c|}
\hline \multicolumn{2}{|l|}{ RAS prevalence $(\%)$} & \multicolumn{3}{|c|}{ Population studies } & \multirow[t]{2}{*}{ References } \\
\hline Clinical examination & Patient's history & Country & Number of participants & Age of participants & \\
\hline 1.2 & & USA & 7,785 & $17-39$ & Rivera-Hidalgo et al. (2004) \\
\hline 0.59 & & & 9,450 & $\geq 40$ & \\
\hline 1.03 & & USA & 33,994 & $<1$ to $\geq 60$ & Chattopadhyay and Chatterjee (2007) \\
\hline 1.2 & & Turkey & 765 & $5-95$ & Mumcu et al. (2005) \\
\hline 1.4 & 18.3 & Germany & 655 & $35-44$ & Reichart (2000) \\
\hline \multirow[t]{3}{*}{1.0} & 6.9 & & 1,367 & $65-74$ & \\
\hline & 9.7 & Slovenia & 555 & $15-65$ & Kovač-Kovačič and Skalerič (2000) \\
\hline & 78.1 & Jordan & 684 & $13-68$ & Safadi (2009) \\
\hline 2 & 27.3 & Poland & 814 & $14-18$ & Górska (1997a) \\
\hline 7.6 & & Poland & 1,216 & $10-79$ & Szponar et al. (2006) \\
\hline 10.0 & & Poland & 1,281 & $\mathrm{ND}^{\mathrm{a}}$ & Konopka and Mendak (2004) \\
\hline 3.6 & & Poland & 1,500 & $\mathrm{ND}^{\mathrm{a}}$ & Bizoń-Wróblewska et al. (1997) \\
\hline
\end{tabular}

${ }^{a}$ Not defined in the study project

when compared with the studies based on the information from the patient's history. However, the recurrent nature of this condition makes the data from the medical history very relevant in defining the final prevalence of the disease. The comparison of RAS prevalence evaluated based on the results of clinical examination and the information from patient's history in some international research in correlation with age is presented in Table 2 .

The second life decade is considered as a peak period of the RAS occurrence with the first episode in childhood or in later life stages. As in the other diseases with possible autoimmune-mediated diseases, early age at onset does not necessarily need to be related with a worse prognosis (Amador-Pattaroyo et al. 2012). Based on epidemiologic observations, MaRAS appears more frequently in younger patients, while HeRAS affects most commonly people in third life decade (Chattopadhyay and Chatterjee 2007; Natah et al. 2004; Tappuni et al. 2013; Woo and Sonis 1996). The mechanism of the development of particular type of RAS in correlation with patient's age has not been clearly understood so far. Although the RAS is generally a common oral mucosal condition; herpetiform type is observed rarely, which makes the comparisons between the types' occurrence difficult, as most of the reports refer to MaRAS or MiRAS. More profound analysis in this matter is definitely indicated. Generally, the severity and frequency of the episodes vary individually; however, it usually decreases with age, as presented in Table 2 (McCullough et al. 2007; Reichart 2000; Shulman 2004; Sook-Bin and Sonis 1996; Wolach et al. 2012). The reduced occurrence of RAS in elderly in comparison to young patients may partially result from age-dependent alterations in the innate and the adaptive components of the immune system, described as immunosenescence and "inflamm-aging" (DeVeale et al. 2004; Franceschi et al. 2000; Plowden et al. 2004; Senovilla et al. 2013). In elderly, the neutrophils' chemotactic and phagocytic capacity decreases and the reduced proportion of naive $\mathrm{T}$ 
cells relative to their memory counterparts occurs (Maheaswari et al. 2013; Stankiewicz and Stasiak-Barmuta 2011). Apart from the shifts in population types, immune cells also exhibit altered cytokine production and responsiveness, reduced proliferative responses, signal transduction defects and diminished antigen recognition (Campisi et al. 2009; Maheaswari et al. 2013; Wardzyńska and Kowalski 2009). The prevalence of autoimmune diseases is relatively low in elderly patients also due to agerelated increase in peripheral $\mathrm{CD}^{+}{ }^{+} \mathrm{CD} 25^{\text {high }} \mathrm{FOXP} 3^{+}$ T-regulatory cells (Vadasz et al. 2013). This process may also be involved in RAS.

Apart from the age-related differences in the prevalence, the condition is found three times more often in white citizens than in Afro-Americans (Matranga et al. 2012). Also non-smoking subjects are more prone to develop RAS in comparison to tobacco smokers and smokeless tobacco users (Chattopadhyay and Chatterjee 2007; Grady et al. 1992; Rivera-Hidalgo et al. 2004). Many epidemiologic studies confirmed the higher incidence of RAS in people with a high socio-economic status (McCullough et al. 2007; RiveraHidalgo et al. 2004). Also females seem to be in a higher risk of the disease development in comparison to males (McCullough et al. 2007; Rivera-Hidalgo et al. 2004).

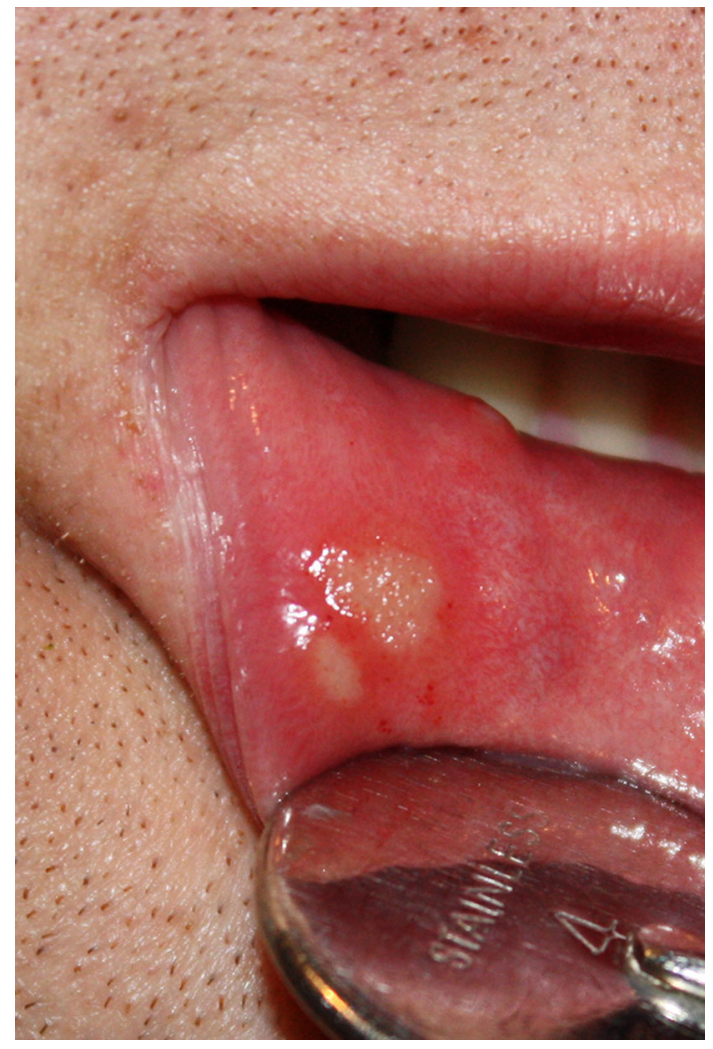

Fig. 1 Minor (Mikulicz) aphtha on the lower lip in a patient of the Department of Oral Mucosa Diseases
Minor (Mikulicz) aphtha on the lower lip in a male patient of the Department of Oral Mucosa Diseases is presented in Fig. 1.

\section{Etiopathogenesis of RAS}

The etiopathogenesis of RAS so far remains not fully understood. The potential trigger factors include: genetic predisposition, viral and bacterial infections, food allergies, vitamin and microelement deficiencies, systemic diseases (e.g., celiac disease, Crohn's disease, ulcerative colitis, AIDS), increased oxidative stress, hormonal defects, mechanical injuries and anxiety (Bilgili et al. 2013; Field and Allan 2003; Koybasi et al. 2006; McCullough et al. 2007; Natah et al. 2004; Scully and Porter 2008). Recently, also the atopic background of the condition has been suggested (Veller-Fomasa and Gallina 2006). In genetically predisposed patients, the effect of certain trigger factors initiates the cascade of proinflammatory cytokines, directed against selected regions of the oral mucosa. The microscopic observation of the aphtha region reveals a massive leukocytic infiltration, which varies depending on the disease duration and severity. In the initial phase which precedes the ulcer formation, monocytes and lymphocytes (mainly of the T type) together with single mast and plasmatic cells accumulate under the basal cell layer. In more advanced stages, polynuclear leukocytes dominate in the center of the ulcer, while on the lesion border the abundant mononuclear cell infiltration can be observed (Mills et al. 1980; Poulter and Lehner 1989). According to Poulter and Lehner (1989), this characteristic of the inflammatory infiltration is not

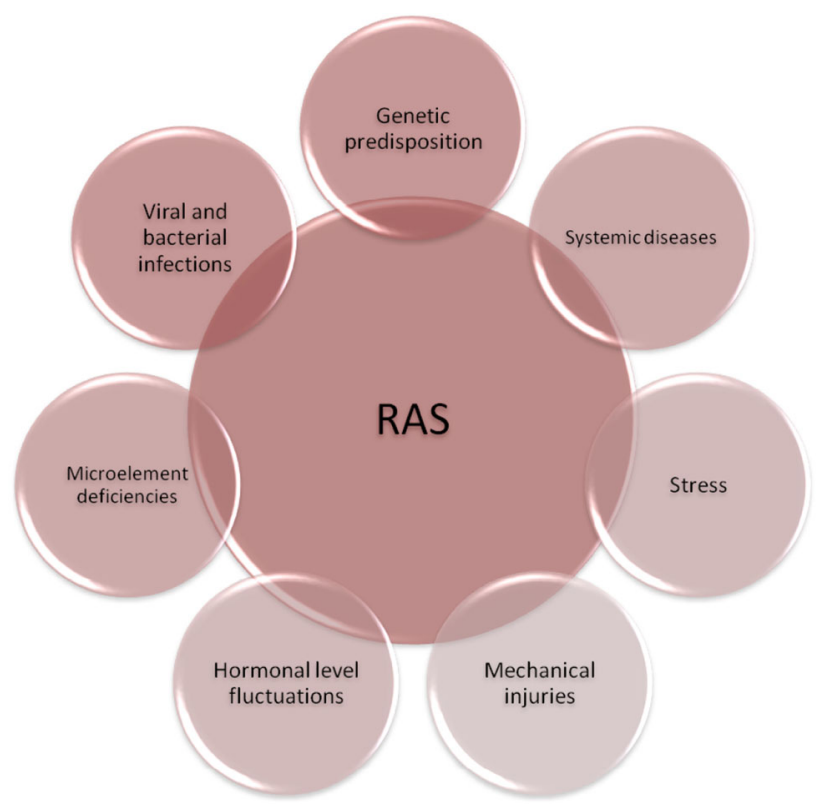

Fig. 2 Modifying factors of the immunologic response in RAS 
exclusively specific to RAS and does not differ from the one observed in Behçet's syndrome, erythema multiforme, lupus erythematosus and traumatic ulcers.

Factors that modify the course of the immune response in RAS are presented in Fig. 2.

\section{Genetic Predisposition}

First reports on the role of genetic predisposition in the development of RAS are dated to the middle 1960s of the twentieth century. Based on the observation of the families suffering from RAS, Ship (1965) and Miller et al. (1977) propounded the autosomal recessive or multigene mode of inheritance with modifying influence of the environment. The role of genetic factors in the etiopathogenesis of recurrent aphthae was confirmed in further studies of relatives and twins with RAS, where the positive family history of the disease was reported in $24-46 \%$ of cases (Rogers 1997; Scully and Porter 2008). The disease in parents significantly influences the risk of RAS and the course of the condition in their children-patients with a positive family history of RAS suffer more frequent recurrences and more severe course of the disease comparing to those with a negative RAS family history (Almoznino et al. 2013; Lehner 1978; Yilmaz and Cimen 2010). Moreover, in both, RAS and Behçet's syndrome, the risk of the disease development was higher in monozygotic twins than in dizygotic ones (Kobayashi et al. 2005; Yilmaz and Cimen 2010). The genetic risk factors that modify the individual susceptibility to RAS include various DNA polymorphisms distributed in the human genome, especially those related with the alterations in the metabolism of interleukins (IL$1 \beta$, IL-2, IL-4, IL-5, IL-6, IL-10, IL-12), interferon (IFN)- $\gamma$ and tumor necrosis factor (TNF)- $\alpha$ (Akman et al. 2006, 2008; Bazrafshani et al. 2002, 2003; Buño et al. 1998; Guimarães et al. 2006, 2007; Hall et al. 2000; Kalkan et al. 2013; Pekiner et al. 2012). The role of DNA polymorphisms in serotonin transporter gene, endothelial nitric oxide synthase gene and cell adhesion molecule genes has also been considered (Alkhateeb et al. 2013; Gallo et al. 2012; Karasneh et al. 2005, 2009; Kim et al. 2003; Oksel et al. 2006; Salvarani et al. 2002; Victoria et al. 2005; Wang and Wang 2000). Other researchers reported the correlation between the selected HLA allele and the increased risk of RAS and Behçet's syndrome (Albanidou-Farmaki et al. 2008; Challacombe et al. 1977; Sun et al. 2001). In patients with RAS, a higher incidence of HLA-A33, HLA-B35 and HLA-B81 (Wilhelmsen et al. 2009), HLA-B12 (Lehner et al. 1982), HLA-B51 (Özdemir et al. 2009), HLA-DR7 and HLA-DR5 and lower incidence of HLA-B5 and HLA-DR4 (Albanidou-Farmaki et al. 1988; Gallina et al. 1985) was observed when compared to healthy controls.

\section{Bacterial and Viral Infections}

Among the potential factors with the ability to modify the immunologic response and to invoke recurrent aphthae in predisposed subjects some authors mention bacterial (Streptococcus oralis, Helicobacter pylori) and viral (herpes simplex virus, varicella-zoster virus, cytomegalovirus, adenoviruses) antigens. The studies' results, however, are ambiguous and conflicting (Barile et al. 1963; Donatsky 1976; Natah et al. 2004; Shimoyama et al. 2000; Sook-Bin and Sonis 1996). The elevated serum level of antibodies against some streptococcal strains in RAS patients reported in the 1960s was not confirmed in latter studies, similarly in the case of antibodies against $H$. pylori (Barile et al. 1963; Donatsky 1976; Fritscher et al. 2004; MansourGhanaei et al. 2005; Shimoyama et al. 2000). Tas et al. (2013) proved the beneficial effect of $H$. pylori eradication in patients with RAS. The underlying mechanism, however, is rather related with the increase in serum vitamin B12 levels after the eradication than with the direct action of the bacteria. The attempts to isolate herpes simplex, cytomegalovirus, varicella-zoster and Epstein-Barr viral DNA from the biologic material collected from aphthae and mononuclear peripheral blood cells were successful only in single case of RAS, which also does not confirm the direct role of viruses in the etiopathogenesis of the condition (Natah et al. 2004). Also Greenspan et al. (1985) concluded that neither cell-mediated hypersensitivity to streptococcal or viral antigens nor cross-reactivity between oral mucosal and streptococcal antigens is likely to play a role in the pathogenesis of RAS.

\section{Food Allergies and Microelement Deficiencies}

In some patients with RAS, the deficiency in hematins (iron, folic acid, vitamin B12) was revealed (Khan et al. 2013; Lopez-Jornet et al. 2013; Natah et al. 2004; Olson et al. 1982; Scully and Porter 2008; Sook-Bin and Sonis 1996; Volkov et al. 2009); however, their modifying influence on the course of the immune response in RAS seems to be limited. In research by Lalla et al. (2012), Nolan et al. (1991a, b), Porter et al. (1992) and HaisraeliShalish et al. (1996), the supplementation of lacking microelements modified the disease course only in a small percentage of patients. Contrary, Volkov et al. (2009) observed positive effects of the oral vitamin B12 supplementation in RAS subjects regardless of the initial serum levels of this microelement. Some reports on the role of zinc deficiency in RAS were also published. Up to now, the theory was not unequivocally confirmed and the studies' results are conflicting (Endre 1991; Pang 1992). 
According to some researchers, also the exposition to some food ingredients, e.g., chocolate, gluten, cow milk, preservatives, nuts and food coloring agents may induce the pro-inflammatory cascade in RAS (Natah et al. 2004; Eversole et al. 1982; Sook-Bin and Sonis 1996; Wardhana 2010). In some patients, the clinical improvement was observed after inducing the elimination diet. In their double-blind study, Hunter et al. (1993) concluded that also the placebo-effect probably modifies the course of RAS- the clinical improvement was observed in both study groups: patients on real elimination diet and patients on a regular diet, exposed to potential trigger food ingredients. Meanwhile, Tarakji et al. (2012) did not confirm any important role of dietary habits in development of RAS.

\section{Systemic Diseases and Hormonal Imbalance}

Based on many studies' results, recurrent aphthae appear more frequently in patients with gastro-intestinal disturbances, mainly those from the group of chronic inflammatory bowel diseases (Crohn's disease, ulcerative colitis) and celiac disease (Aydemir et al. 2004; Hunter et al. 1993; Olszewska et al. 2006; Rogers 1997; Scully and Porter 2008). This correlation may partially result from the food and microelement deficiencies - a characteristic complication in this group of the diseases (Natah et al. 2004). The coincidence of aphthae with inflammatory bowel diseases and celiac disease may also be related with autoimmune reactions, assumed as a background of all the mentioned conditions (Woźniak-Stolarska et al. 2003). Aphthae were also a frequent finding in HIV-infected persons, who manifested the disproportion of CD4 and CD8 lymphocytes together with decreased neutrophil count (MacPhail et al. 1991; Miziara et al. 2005; Muzyka and Glick 1994; Nesti et al. 2012).

Some reports mention also the correlation between the serum levels of sexual hormones and the course of RAS. Exacerbations of the condition were observed mainly in the luteal phase of the menstrual cycle and during the menopause, while the remissions seem to appear often during pregnancy and in women on contraceptives (Natah et al. 2004; Scully et al. 2003; Sook-Bin and Sonis 1996).

\section{Mechanical Injuries}

In many RAS-predisposed patients, the lesions appear on the oral mucosa shortly after mechanical irritation of the area; however, the mechanism of this reaction remains not fully understood (Natah et al. 2004, Scully et al. 2003, Sook-Bin and Sonis 1996, Wray et al. 1981). Polańska et al. (2006) suggested the role of neutrophil elastase in the process of post-traumatic formation of aphthous ulcer. On the other hand, based on the epidemiologic observations, most of the researchers indicate the lower incidence of RAS in smokers in comparison to non-smoking subjects, with a correlation with habit duration and severity (Axell and Henricsson 1985; Bittoun 1991; Sawair 2010; Tuzun et al. 2000). That could be explained by a higher level of oral mucosa keratinization in response to smoking, which makes it less prone to injury and irritation (Natah et al. 2004; Scully et al. 2003; Sook-Bin and Sonis 1996). Nicotine and its metabolites can also decrease the level of proinflammatory cytokines (TNF- $\alpha$, IL-1 and IL-6) and increase the level of anti-inflammatory IL-10 (Subramanyam 2011). Also smokeless tobacco products seem to decrease the risk of RAS development (Grady et al. 1992).

\section{Stress}

Another described factor potentially related with RAS exacerbations is stress (Natah et al. 2004; Keenan and Spivakovksy 2013; Scully et al. 2003; Sook-Bin and Sonis 1996; Volkov et al. 2009; Zadik et al. 2012). According to some authors, it rather triggers the onset of the episode than influences its duration (Huling et al. 2012; Keenan and Spivakovksy 2013). Psychogenic effects modify the immune response also in the other conditions with a suspected autoimmune background, like lichen planus and chronic inflammatory bowel diseases (Soto Araya et al. 2004).

\section{Mechanisms of the Immune Response in RAS}

The basic mechanisms of the immunologic response disruption in RAS are illustrated in Fig. 3.

One of the important factors that may induce and determine the type of the immune response in the human body is the cytokines (Konopka et al. 1995). Th1 type cytokines, which include: IL-2, IL-12, IFN- $\gamma$ and TNF- $\alpha$, determine the predisposition towards autoimmunisation, induce the cellular type response and stimulate the secretion of $\mathrm{IgG}$. Th2 type cytokines, including: IL-4, IL-5, IL-10 and IL-13, manifest anti-inflammatory properties, stimulate the humoral immune response and the secretion of IgE. Strong anti-inflammatory effect is contributed also to another cytokine called transforming growth factor (TGF)- $\beta$, secreted mainly by the T-regulator lymphocytes (Buño et al. 1998; Lewkowicz et al. 2004). It was found that aphthous ulcer develops in response to the enhanced immunologic reaction against particular regions of the oral mucosa (Borra et al. 2004; Eversole 1994; Lewkowicz et al. 2004). This reaction occurs in a result of improperly initiated cascade of cytokines, which activate 
Fig. 3 Mechanisms of the disrupted immunologic response in RAS

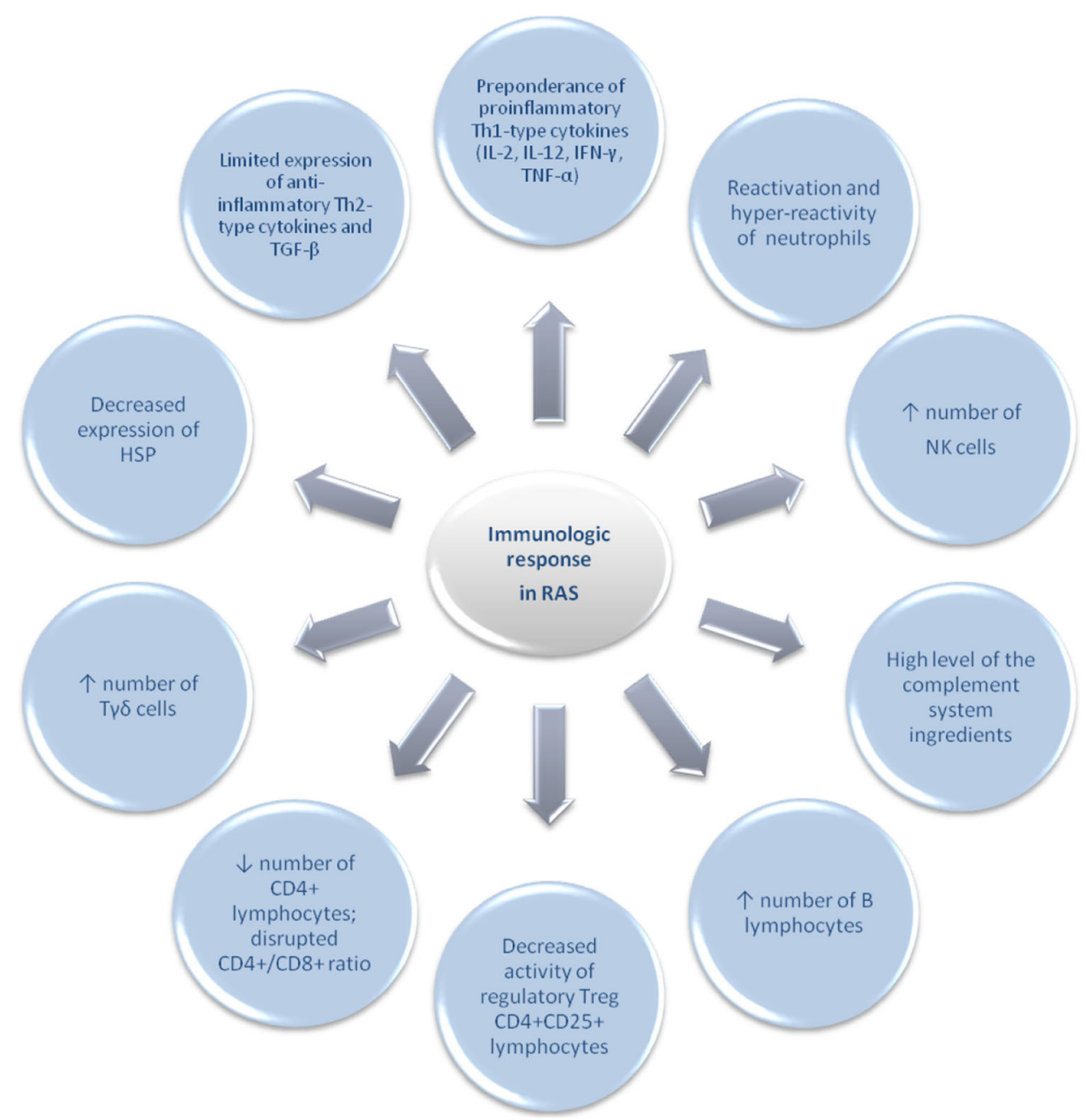

certain immune processes (Borra et al. 2004; Lewkowicz et al. 2004). It was found that in patients with RAS, the immune system's function become disrupted in response to some kind of not yet defined trigger factor, which may include viral and bacterial antigens or stress. In many reports also the role of the autoimmunisation in the disease development was emphasized (Borra et al. 2004; Górska 1997b; Hietanen et al. 2012; Malmström et al. 1983). Both types of the immune response: natural and acquired (humoral and cellular) may become disturbed in patients with RAS, which, among the others, manifests with neutrophils' reactivation and hyper-reactivity, elevated concentration of the complement ingredients, increased number of $\mathrm{NK}$ cells and $\mathrm{B}$ lymphocytes, disrupted $\mathrm{CD} 4^{+} / \mathrm{CD}^{+}$ratio and increased number of $\mathrm{CD} 25^{+}$and $\mathrm{T}$ cell receptor (TCR) $\gamma \delta$ cells in peripheral blood (Eversole 1997; Lewkowicz et al. 2003; Nowak and Górska 2008). Therefore, to determine the mechanism of the immunologic response in RAS, it was necessary to define the cytokine profile in patients suffering from this disease. Many authors suggest that the Th1 type immunologic response is the one to play the crucial role in the development of RAS (Albanidou-Farmaki et al. 2007; Borra et al. 2004; Buño et al. 1998; Lewkowicz et al. 2004, 2011).

Significantly higher secretion of Th1 cytokines in RAS patients in comparison to the controls was described by Lewkowicz et al. (2004). The increased production of IL-2, IFN- $\gamma$ and TNF- $\alpha$ by the peripheral blood mononuclear cells was observed both in the acute phase of the disease and in the remission. Meanwhile, the secretion of antiinflammatory cytokines TGF- $\beta$ and IL-10 was significantly decreased in RAS patients compared to the healthy controls. This observation confirms that the imbalance in proand anti-inflammatory cytokines' production may contribute to the development of autoimmunisation and RAS in predisposed subjects. Similarly, Albanidou-Farmaki et al. (2007) found the increased number of T lymphocytes able to produce pro-inflammatory cytokines (IL-2, IL-12 and IFN- $\gamma$ ) and the decreased number of IL-10-producing cells in peripheral blood of the RAS patients in comparison to the healthy controls. Also Borra et al. (2004) demonstrated the increased expression of Th1 type response gene cluster 
in comparison to Th2 gene cluster in patients with RAS. The authors emphasized that also some physiologic states or therapeutics (e. g. pregnancy, nicotine exhibition, glucocorticoid, thalidomide and tetracycline treatment) are well known as the Th1 type immunologic response inhibitors; therefore, they may influence the course of RAS. Increased activity of the Th1 type immunologic response was also observed in some other autoimmune-mediated conditions like Crohn's disease, celiac disease and PFAPA (periodic fever, aphthous stomatitis, pharyngitis and adenitis) syndrome (Yao and Furst 2008). Apart from the decreased expression of anti-inflammatory cytokines, significantly decreased expression of heat shock protein 27 was observed in the oral mucosa of the RAS patients (Miyamoto et al. 2008). Heat shock proteins manifest the property to inhibit the expression of pro-inflammatory cytokines and they participate in the inhibition of the monocytes differentiation into the dendritic cells. The decrement in the concentration of that protein fraction may, therefore, exacerbate the inflammation. The elevated levels of heat shock protein were observed in tobacco smokers, which may partially explain the phenomenon of the lower incidence of aphthae in smokers compared to non-smokers (Miyamoto et al. 2008). Moreover, in the latter study, Lewkowicz et al. (2008) demonstrated the decreased efficacy of Treg $\mathrm{CD} 4{ }^{+} \mathrm{CD} 25^{+}$cells in the inhibition of the proinflammatory cytokines' secretion by $\mathrm{CD}^{+}$effector $\mathrm{T}$ lymphocytes in the RAS patients compared to the controls with no systemic diseases.
Buño et al. (1998) attempted to determine the concentration of pro-inflammatory cytokines directly in the oral mucosa of patients with RAS and they demonstrated significantly increased levels of IL-2, IL-4, IL-5, IFN- $\gamma$ and TNF- $\alpha$ together with a decreased concentration of antiinflammatory cytokine IL-10 in the examined group when compared to healthy controls. These results indicate that the complex mode of the immune response participates in the development of RAS. On the one hand, the authors demonstrated the elevated concentration of pro-inflammatory cytokines in the oral mucosa affected with aphthae (Th1 type response), but on the other hand the increased levels of Th2 type cytokines (IL-4, IL-5) were also detected.

Nowak and Górska (2008) compared the concentration of IL-2 in the peripheral blood and in stimulated saliva in patients with RAS and in healthy volunteers. They have demonstrated significantly increased levels of this proinflammatory cytokine in the blood samples of RAS patients in comparison to controls; however, no significant differences were detected in stimulated saliva. According to the authors these results suggests that IL-2 can be produced by $\mathrm{T}$ lymphocytes.

The role of TNF- $\alpha$, another pro-inflammatory cytokine, in the development of aphthae was confirmed in the study by Natah et al. (2000a), who compared the number of TNF$\alpha$-containing cells in the oral mucosa affected by aphthae and in the mechanically injured oral mucosa bioptates. Cells rich in TNF- $\alpha$ were observed much more frequently

Table 3 The role of inflammatory mediators in the etiopathogenesis of RAS and the mechanisms of the immune system disruption based on the literature reports

\begin{tabular}{|c|c|c|c|}
\hline Mediator & $\begin{array}{l}\text { Tissue } \\
\text { studied }\end{array}$ & Mechanism of the immune system disruption in RAS & References \\
\hline $\begin{array}{l}\text { IL- } 2, \text { IFN- } \gamma, \text { TNF- } \alpha \\
\text { TGF- } \beta, \text { IL-10 }\end{array}$ & PBMC & $\begin{array}{l}\uparrow \text { production } \\
\downarrow \text { production }\end{array}$ & Lewkowicz et al. (2004); Poland \\
\hline $\begin{array}{l}\text { IL-2, IL-12, IFN- } \gamma \\
\text { IL-10 }\end{array}$ & PBMC & $\begin{array}{l}\uparrow \text { production } \\
\downarrow \text { production }\end{array}$ & Albanidou-Farmaki et al. (2007); Greece \\
\hline $\begin{array}{l}\text { IL-2, IL-4, IL-5, IFN- } \gamma, \text { TNF- } \alpha \\
\text { IL-10 }\end{array}$ & Oral mucosa & $\begin{array}{l}\uparrow \text { concentration } \\
\downarrow \text { concentration }\end{array}$ & Buño et al. (1998); USA \\
\hline IL-2 & $\begin{array}{l}\text { Blood } \\
\text { Saliva }\end{array}$ & $\begin{array}{l}\uparrow \text { concentration } \\
\text { No differences between RAS subjects and healthy } \\
\text { controls }\end{array}$ & Nowak and Górska (2008); Poland \\
\hline TNF- $\alpha$ & $\begin{array}{l}\text { Oral mucosa } \\
\text { Oral mucosa } \\
\text { Blood } \\
\text { Oral mucosa }\end{array}$ & $\begin{array}{l}\uparrow \text { concentration of TNF- } \alpha \text {-containing cells } \\
\uparrow \text { concentration of TCR } \gamma \delta \text { lymphocytes } \\
\uparrow \text { concentration of TCR } \gamma \delta \text { lymphocytes } \\
\uparrow \text { expression of Th1 type response gene cluster } \\
\text { compared to Th2 }\end{array}$ & $\begin{array}{l}\text { Natah et al. (2000a); Finland } \\
\text { Natah et al. (2000b); Finland } \\
\text { Freysdottir et al. (1999); Great Britain } \\
\text { Borra et al. (2004); Brazil }\end{array}$ \\
\hline $\begin{array}{l}\text { IL-10 } \\
\text { HSP27 }\end{array}$ & Oral mucosa & $\downarrow$ tissue expression & Miyamoto et al. (2008); Brazil \\
\hline & & $\begin{array}{l}\downarrow \text { Treg } \mathrm{CD}^{+} \mathrm{CD}^{2} 5^{+} \text {efficacy in the inhibition of } \\
\text { proinflammatory cytokines secretion by the effector } \\
\mathrm{CD} 4^{+} \mathrm{T} \text { lymphocytes }\end{array}$ & Lewkowicz et al. (2008); Poland \\
\hline
\end{tabular}

PBMC peripheral blood mononuclear cells, HSP27 heat shock protein 27 
in biologic material received from the RAS patients, which suggests the role of the tested cytokine in the lymphocytes activation and recruitment in the course of the disease. In the other study, Natah et al. (2000b) also found a significant elevation of TCR $\gamma \delta$ cells number in the oral mucosa with aphthous lesions. Lymphocytes with $\mathrm{T} \gamma / \delta$ cell receptors produce IL-2, manifest cytotoxic properties and destroy some certain virus-infected cells. They also play role in the process of epithelial growth control. Previous observations confirmed the elevated concentration of that type cells in the subjects with rheumatoid arthritis, tuberculosis and celiac disease. The results of Natah et al. (2000b) study revealed that the local elevation in TCR $\gamma \delta$ cells number was also found in the oral mucosa in RAS patients. However, the biological role of those cells in the process of the aphthous ulcer formation and healing still remains not clearly understood. Similar conclusions were presented by Freysdottir et al. (1999), who observed the increased TCR $\gamma \delta$ cells' concentration in the peripheral blood of patients with Behçet's syndrome and RAS.

In Table 3, we summarized the role of inflammatory mediators in the etiopathogenesis of RAS based on Polish and foreign studies.

The common occurrence of aphthae was also described in patients with HIV, who manifested the disturbed proportion of CD4 and CD8 lymphocytes (Aydemir et al. 2004). The decreased CD4:CD8 ratio has been also found in RAS patients not affected by HIV; studies results, however, are not consistent in this matter (Aydemir et al. 2004; Lewkowicz et al. 2008).

Ambiguous conclusions on the immunologic processes in RAS were also stated in studies performed with the use of immunofluorescent methods. Wilhelmsen et al. (2008) did not reveal the deposits of immune complexes in the oral mucosa specimens received from patients with RAS. Such deposits are characteristic for certain autoimmune-mediated vesiculo-bullous diseases, like Pemphigus vulgaris and Pemphigoid. The lack of immune complexes in RAS could, therefore, become an important differentiating marker between RAS and vesiculo-bullous diseases. Some other authors, however, observed the deposits of IgG, IgM and IgA in the epithelial stratum spinosum in RAS and in Behçet syndrome (Williams and Lehner 1977).

\section{Conclusion}

The presented studies' results confirm the crucial role of the immunologic disturbances in the etiopathogenesis of RAS. Conclusions from the genetic research support the thesis that the immune system's hyper-reactivity in response to some trigger factors in patients with RAS is at least partially related with a genetic predisposition-certain polymorphisms in the cytokine encoding genes implicate a higher predisposition to RAS. As the etiopathogenesis of the condition has not been clearly defined, the treatment is mainly symptomatic and not very effective. Discovering the direct etiopathogenetic factors in RAS may in future help to predict the risk of the disease occurrence and to develop the effective, causative management. Inconsistent results of the multiple international studies focused on genetic and immunologic background of the condition and insufficient number of that type research on Polish population indicate a necessity to perform such an analysis also in our country.

Conflict of Interest The authors declare that they have no conflict of interest.

Open Access This article is distributed under the terms of the Creative Commons Attribution License which permits any use, distribution, and reproduction in any medium, provided the original author(s) and the source are credited.

\section{References}

Akman A, Sallakci N, Coskun M et al (2006) TNF- $\alpha$ gene 1031 T/C polymorphism in Turkish patients with Behçet's disease. Br J Dermatol 155:350-356

Akman A, Ekinci NC, Karcaroglu H et al (2008) Relationship between periodontal findings and specific polymorphisms of interleukin- $1 \alpha$ and $-1 \beta$ in Turkish patients with Behçet's disease. Arch Dermatol Res 300:19-26

Albanidou-Farmaki E, Kayavis IG, Polymenidis Z et al (1988) HLAA, B, C, and DR antigens in recurrent oral ulcers. Ann Dent 47:5-8

Albanidou-Farmaki E, Markopoulos AK, Kalogerakou F et al (2007) Detection, enumeration and characterization of $\mathrm{T}$ helper cells secreting type 1 and type 2 cytokines in patients with recurrent aphthous stomatitis. Tohoku J Exp Med 212:101-105

Albanidou-Farmaki E, Deligiannidis A, Markopoulos AK et al (2008) HLA haplotypes in recurrent aphthous stomatitis: a mode of inheritance? Int J Immunogenet 35:427-432

Alkhateeb A, Karasneh J, Abbadi H et al (2013) Association of cell adhesion molecule gene polymorphisms with recurrent aphthous stomatitis. J Oral Pathol Med. doi:10.1111/jop.12100

Almoznino G, Zini A, Mizrahi Y et al (2013) Elevated serum IgE in recurrent aphthous stomatitis and associations with disease characteristics. Oral Dis. doi:10.1111/odi.12131

Amador-Pattaroyo MJ, Rodriguez-Rodriguez A, Montoya Ortiz G (2012) How does age at onset influence the outcome of autoimmune diseases. Autoimmune Dis 2012:251730

Axell T, Henricsson V (1985) Association between recurrent aphthous ulcers and tobacco habits. Scand J Dent Res 93:239-242

Aydemir S, Solak Tekin N et al (2004) Celiac disease in patients having recurrent aphthous stomatitis. Turk J Gastroenterol 15:192-195

Barile MF, Graykowski EA, Driscoll EJ et al (1963) L form of bacteria isolated from recurrent aphthous stomatitis lesions. Oral Surg Oral Med Oral Pathol 16:1395-1402 
Bazrafshani MR, Hajeer AH, Ollier WE et al (2002) IL-1B and IL-6 gene polymorphisms encode significant risk for the development of recurrent aphthous stomatitis (RAS). Genes Immun 3:302-305

Bazrafshani MR, Hajeer AH, Ollier WE et al (2003) Polymorphisms in the IL-10 and IL-12 gene cluster and risk of developing recurrent aphthous stomatitis. Oral Dis 9:287-291

Bilgili SG, Ozkol H, Takci Z et al (2013) Assessment of the serum paraoxonase activity and oxidant/antioxidant status in patients with recurrent aphthous stomatitis. Int J Dermatol. doi:10.1111/ ijd.12084

Bittoun R (1991) Recurrent aphthous ulcers and nicotine. Med J Aust $154: 471-472$

Bizoń-Wróblewska M, Książek-Bąk H, Wojnar-Kalina A et al (1997) Występowanie chorób błony śluzowej jamy ustnej u pacjentów leczonych w poradni Katedry i Zakładu Stomatologii Zachowawczej i Chorób Przyzębia ŚAM. Stomat Współczesna $4: 283-289$

Borra RC, Andrade PM, Silva ID et al (2004) The Th1/Th2 immunetype response of the recurrent aphthous ulceration analyzed by cDNA microarray. J Oral Pathol Med 33:140-146

Buño IJ, Huff C, Weston WL et al (1998) Elevated levels of interferon gamma, tumor necrosis factor $\alpha$, interleukins 2,4 , and 5 , but not interleukin 10, are present in recurrent aphthous stomatitis. Arch Dermatol 134:827-831

Burruano F, Tortorici S (2000) Major aphthous stomatitis (Sutton's disease): etiopathogenesis, histological and clinical aspects. Minerva Stomatol 49:41-50

Campisi G, Chiappelli M, De Martinis M et al (2009) Pathophysiology of age-related diseases. Immun Ageing 6:12

Challacombe SJ, Batchelor JR, Kennedy LA et al (1977) HLA antigens in recurrent oral ulceration. Arch Dermatol 113:1717-1719

Chattopadhyay A, Chatterjee S (2007) Risk indicators for recurrent aphthous ulcers among adults in the US. Community Dent Oral Epidemiol 35:152-159

Chavan M, Jain H, Diwan N et al (2012) Recurrent aphthous stomatitis: a review. J Oral Pathol Med 41:577-583

DeVeale B, Brummel T, Seroude L (2004) Immunity and aging: the enemy within? Aging Cell 3:195-208

Donatsky O (1976) Comparison of cellular and humoral immunity against streptococcal and adult oral mucosa antigens in relation to exacerbation of recurrent aphthous stomatitis. Acta Pathol Microbiol Scand 84:270-282

Endre L (1991) Recurrent aphthous ulceration with zinc deficiency and cellular immune deficiency. Oral Surg Oral Med Oral Pathol 72:559-561

Eversole LR (1994) Immunopathology of oral mucosal ulcerative, desquamative, and bullous diseases: selective review of the literature. Oral Surg Oral Med Oral Pathol 77:555-571

Eversole LR (1997) Immunopathogenesis of oral lichen planus and recurrent aphthous stomatitis. Semin Cutan Med Surg 16:284-294

Eversole LR, Shopper TP, Chambers DW (1982) Effects of suspected foodstuff challenging agents in the etiology of recurrent aphthous stomatitis. Oral Surg Oral Med Oral Pathol 54:33-38

Field EA, Allan RB (2003) Review article: oral ulcerationaetiopathogenesis, clinical diagnosis and management in the gastrointestinal clinic. Aliment Pharmacol Ther 18:949-962

Franceschi C, Bonafè M, Valensin S et al (2000) Inflamm-aging. An evolutionary perspective on immunosenescence. Ann NY Acad Sci 908:244-254

Freysdottir J, Lau SH, Fortune F (1999) $\gamma \delta$ T cells in Behçet's disease (BD) and recurrent aphthous stomatitis (RAS). Clin Exp Immunol 118:451-457

Fritscher AM, Cherubini K, Chies J et al (2004) Association between Helicobacter pylori and recurrent aphthous stomatitis in children and adolescents. J Oral Pathol Med 33:129-132
Gallina G, Cumbo V, Messina P et al (1985) HLA-A, B, C, DR, MT and $\mathrm{MB}$ antigens in recurrent aphthous stomatitis. Oral Surg Oral Med Oral Pathol 59:364-370

Gallo CB, Borra RC, Rodini CO et al (2012) CC chemokine ligand 3 and receptors 1 and 5 gene expression in recurrent aphthous stomatitis. Oral Surg Oral Med Oral Pathol Oral Radiol 114:93-98

Górska R (1997a) Epidemiologic studies of oral mucosa changes occurring in children, adolescents, and adults 13-24 years of age in Warsaw. Przegl Epidemiol 51:339-347

Górska R (1997b) Lymphocyte subpopulations research in the peripheral blood of patients with recurrent aphthous ulceration. Czas Stomatol 10:652-657

Grady D, Ernster VL, Stillman L et al (1992) Smokeless tobacco use prevents aphthous stomatitis. Oral Surg Oral Med Oral Pathol 74:463-465

Greenspan JS, Gadol N, Olson JA et al (1985) Lymphocyte function in recurrent aphthous ulceration. J Oral Pathol 14:592-602

Guimarães AL, Sá AR, Victória JM et al (2006) Association of IL-1 $\beta$ polymorphism with recurrent aphthous stomatitis in Brazilian individuals. Oral Dis 12:580-583

Guimarães AL, Correia-Silva Jde F et al (2007) Investigation of functional gene polymorphisms IL- $1 \beta$, IL-6, IL-10 and TNF- $\alpha$ in individuals with recurrent aphthous stomatitis. Arch Oral Biol $52: 268-272$

Haisraeli-Shalish M, Livneh A, Katz J et al (1996) Recurrent aphthous stomatitis and thiamine deficiency. Oral Surg Oral Med Oral Pathol Oral Radiol Endod 82:634-636

Hall MA, McGlinn E, Coakley G et al (2000) Genetic polymorphism of IL-12 p40 gene in immune-mediated disease. Genes Immun $1: 219-224$

Hietanen J, Häyrinen-Immonen R, Al-Samadi A et al (2012) Recurrent aphthous ulcers-a Toll-like receptor-mediated disease? J Oral Pathol Med 41:158-164

Huling LB, Baccaglini L, Choquette L et al (2012) Effect of stressful life events on the onset and duration of recurrent aphthous stomatitis. J Oral Pathol Med 41:149-152

Hunter IP, Ferguson MM, Scully C et al (1993) Effects of dietary gluten elimination in patients with recurrent minor aphthous stomatitis and no detectable gluten enteropathy. Oral Surg Oral Med Oral Pathol 75:595-598

Kalkan G, Yigit S, Karakus N et al (2013) Association between interleukin 4 gene intron 3 VNTR polymorphism and recurrent aphthous stomatitis in a cohort of Turkish patients. Gene 527:207-210

Karasneh JA, Hajeer AH, Silman A et al (2005) Polymorphisms in endothelial nitric oxide synthase gene are associated with Behçet's disease. Rheumatology 44:614-617

Karasneh JA, Bazrafshani R, Thornhill M et al (2009) Endothelial nitric oxide synthase gene polymorphisms are not associated with recurrent aphthous stomatitis. Arch Oral Biol 54:583-587

Keenan AV, Spivakovksy S (2013) Stress associated with onset of recurrent aphthous stomatitis. Evid Based Dent 14:25

Khan NF, Saeed M, Chaudhary S et al (2013) Haematological parameters and recurrent aphthous stomatitis. J Coll Physicians Surg Pak 23:124-127

Kim JU, Chang HK, Lee SS et al (2003) Endothelial nitric oxide synthase gene polymorphisms in patients with Behçet's disease and rheumatic diseases with vasculitis. Ann Rheum Dis 62: 1083-1087

Kobayashi T, Sudo Y, Okamura S et al (2005) Monozygotic twins concordant for intestinal Behçet's disease. J Gastroenterol 40:421-425

Konopka T, Mendak M (2004) Występowanie chorób błony śluzowej jamy ustnej u pacjentów poradni specjalistycznej we Wrocławiu w latach 1992-2003. Dent Med Probl 4:717-725 
Konopka T, Ziętek M, Radwan-Oczko M (1995) Rola interleukin w etiopatogenezie zapaleń przyzębia. Mag Stomatol 6:24-30

Kovač-Kovačič M, Skalerič U (2000) The prevalence of oral mucosal lesions in a population in Ljubljana, Slovenia. J Oral Pathol Med 29:331-335

Koybasi S, Parlak AH, Serin E et al (2006) Recurrent aphthous stomatitis: investigation of possible etiologic factors. Am J Otolaryngol 27:229-232

Lalla RV, Choquette LE, Feinn RS et al (2012) Multivitamin therapy for recurrent aphthous stomatitis: a randomized, double-masked, placebo-controlled trial. J Am Dent Assoc 143:370-376

Lehner T (1978) Immunological aspects of recurrent oral ulceration and Behçet's syndrome. J Oral Pathol 7:424-430

Lehner T, Welsh KI, Batchelor JR (1982) The relationship of HLA-B and DR phenotypes to Behçet's syndrome, recurrent oral ulceration and the class of immune complexes. Immunology 47:581-587

Lewkowicz N, Lewkowicz P, Kurnatowska A et al (2003) Innate immune system is implicated in recurrent aphthous ulcer pathogenesis. J Oral Pathol Med 32:475-481

Lewkowicz N, Banasik M, Tchórzewski H et al (2004) Predominance of production of Th1 type cytokines in recurrent aphthous ulceration. Dent Med Probl 42:655-660

Lewkowicz N, Lewkowicz P, Dzitko K et al (2008) Dysfunction of $\mathrm{CD} 4{ }^{+} \mathrm{CD} 25^{\text {high }} \mathrm{T}$ regulatory cells in patients with recurrent aphthous stomatitis. J Oral Pathol Med 37:454-461

Lewkowicz N, Kur B, Kurnatowska A et al (2011) Expression of Th1/ Th2/Th3/Th17-related genes in recurrent aphthous ulcers. Arch Immunol Ther Exp 59:399-406

Liang MW, Neoh CY (2012) Oral aphthosis: management gaps and recent advances. Ann Acad Med Singapore 41:463-470

Lopez-Jornet P, Camacho-Alonso F, Martos N (2013) Hematological study of patients with aphthous stomatitis. Int $\mathrm{J}$ Dermatol. doi:10.1111/j.1365-4632.2012.05751.x

MacPhail LA, Greenspan D, Feigal DW et al (1991) Recurrent aphthous ulcers in association with HIV infection: description of ulcer types and analysis of T-lymphocyte subsets. Oral Surg Oral Med Oral Pathol 71:678-683

Maheaswari R, Priyadharshini V, Gaurav A (2013) Is immunesenescence a contributing factor for periodontal diseases. J Indian Soc Periodontol 17:169-174

Malmström M, Salo OP, Fyhrquist F (1983) Immunogenetic markers and immune response in patients with recurrent oral ulceration. Int J Oral Surg 12:23-30

Mansour-Ghanaei F, Asmar M, Bagherzadeh AH et al (2005) Helicobacter pylori infection in oral lesions of patients with recurrent aphthous stomatitis. Med Sci Monit 11:CR576-CR579

Matranga D, Di Fede O, Paderni C et al (2012) Demographic and behavioural profiles of patients with common oral mucosal lesions by a homogeneity analysis. Oral Dis 18:396-401

McCullough MJ, Abdel-Hafeth S, Scully C (2007) Recurrent aphthous stomatitis revisited; clinical features, associations, and new association with infant feeding practices? J Oral Pathol Med 36:615-620

Miller MF, Garfunkel AA, Ram C et al (1977) Inheritance patterns in recurrent aphthous ulcers: twin and pedigree data. Oral Surg Oral Med Oral Pathol 43:886-891

Mills MP, Mackler BF, Nelms DC et al (1980) Quantitative distribution of inflammatory cells in recurrent aphthous stomatitis. J Dent Res 59:562-566

Miyamoto NT Jr, Borra RC, Abreu M et al (2008) Immuneexpression of HSP27 and IL-10 in recurrent aphthous ulceration. J Oral Pathol Med 37:462-467

Miziara ID, Filho BCA, Weber R (2005) AIDS and recurrent aphthous stomatitis. Rev Bras Otorrinolaringol 71:517-520
Mumcu G, Cimilli H, Sur H et al (2005) Prevalence and distribution of oral lesions: a cross-sectional study in Turkey. Oral Dis 11:81-87

Muzyka BC, Glick M (1994) Major aphthous ulcers in patients with HIV disease. Oral Surg Oral Med Oral Pathol 77:116-120

Natah SS, Häyrinen-Immonen R, Hietanen J et al (2000a) Immunolocalization of tumor necrosis factor- $\alpha$ expressing cells in recurrent aphthous ulcer lesions (RAU). J Oral Pathol Med 29:19-25

Natah SS, Häyrinen-Immonen R, Hietanen J et al (2000b) Increased density of lymphocytes bearing $\gamma / \delta$ T-cell receptors in recurrent aphthous ulcerations (RAU). Int J Oral Maxillofac Surg 29: 375-380

Natah SS, Konttinen YT, Enattah NS et al (2004) Recurrent aphthous ulcers today: a review of growing knowledge. Int $\mathrm{J}$ Oral Maxillofac Surg 33:221-234

Nesti M, Carli E, Giaquinto C et al (2012) Correlation between viral load, plasma levels of CD4-CD8 T lymphocytes and AIDSrelated oral diseases: a multicentre study on $30 \mathrm{HIV}+$ children in the HAART era. J Biol Regul Homeost Agents 26:527-537

Nolan A, Lamey PJ, Milligan KA et al (1991a) Recurrent aphthous ulceration and food sensitivity. J Oral Pathol Med 20:473-475

Nolan A, McIntosh WB, Allam BF et al (1991b) Recurrent aphthous ulceration: vitamin $\mathrm{B} 1, \mathrm{~B} 2$ and $\mathrm{B} 6$ status and response to replacement therapy. J Oral Pathol Med 20:389-391

Nowak M, Górska R (2008) Comparison of IL-2 concentration in peripheral blood and stimulated saliva found in individuals suffering from recurrent aphthous stomatitis (RAS) and in healthy ones. Czas Stomatol 61:387-394

Oksel F, Keser G, Ozmen M et al (2006) Endothelial nitric oxide synthase gene Glu298Asp polymorphism is associated with Behçet's disease. Clin Exp Rheumatol 24:S79-S82

Olson JA, Feinberg I, Silverman S Jr et al (1982) Serum vitamin B12, folate, and iron levels in recurrent aphthous ulceration. Oral Surg Oral Med Oral Pathol 54:517-520

Olszewska M, Sulej J, Kotowski B (2006) Frequency and prognostic value of $\operatorname{IgA}$ and $\operatorname{IgG}$ endomysial antibodies in recurrent aphthous stomatitis. Acta Derm Venereol 86:332-334

Özdemir M, Acar H, Deniz F et al (2009) HLA-B*51 in patients with recurrent aphthous stomatitis. Acta Derm Venereol 89:202-203

Pang JF (1992) Relation between treatment with traditional Chinese medicine for recurrent aphthous ulcer and human zinc and copper. Zhongguo Zhong Xi Yi Jie He Za Zhi 12:280-282

Pekiner FN, Aytugar E, Demirel GY et al (2012) Interleukin-2, interleukin-6 and $\mathrm{T}$ regulatory cells in peripheral blood of patients with Behçet's disease and recurrent aphthous ulcerations. J Oral Pathol Med 41:73-79

Plowden J, Renshaw-Hoelscher M, Engleman C et al (2004) Innate immunity in aging: impact on macrophage function. Aging Cell 3:161-167

Polańska B, Niemczuk M, Augustyniak D et al (2006) Plasma neutrophil elastase in children with recurrent aphthous stomatitis. Centr Eur J Immunol 31:15-17

Porter S, Flint S, Scully C et al (1992) Recurrent aphthous stomatitis: the efficacy of replacement therapy in patients with underlying hematinic deficiencies. Ann Dent 51:14-16

Poulter LW, Lehner T (1989) Immunohistology of oral lesions from patients with recurrent oral ulcers and Behçet's syndrome. Clin Exp Immunol 78:189-195

Reichart PA (2000) Oral mucosal lesions in a representative crosssectional study of aging Germans. Community Dent Oral Epidemiol 28:390-398

Rivera-Hidalgo F, Shulman JD, Beach MM (2004) The association of tobacco and other factors with recurrent aphthous stomatitis in an US adult population. Oral Dis 10:335-345 
Rogers RS III (1997) Recurrent aphthous stomatitis: clinical characteristics and associated systemic disorders. Semin Cutan Med Surg 16:278-283

Safadi RA (2009) Prevalence of recurrent aphthous ulceration in Jordanian dental patients. BMC Oral Health 9:31-36

Salvarani C, Boiardi L, Casali B (2002) Endothelial nitric oxide synthase gene polymorphisms in Behçet's disease. J Rheumatol 29:535-540

Sawair FA (2010) Does smoking really protect from recurrent aphthous stomatitis? Ther Clin Risk Manag 6:573-577

Scully C, Porter S (2008) Oral mucosal disease: recurrent aphthous stomatitis. Br J Oral Maxillofac Surg 46:198-206

Scully C, Gorsky M, Lozada-Nur F (2003) The diagnosis and management of recurrent aphthous stomatitis: a consensus approach. J Am Dent Assoc 134:200-207

Senovilla L, Galluzzi L, Zitvogel L et al (2013) Immunosurveillance as a regulator of tissue homeostasis. Trends Immunol. doi:10. 1016/j.it.2013.06.005

Shashy RG, Ridley MB (2000) Aphthous ulcers: a difficult clinical entity. Am J Otolaryngol 21:389-393

Shimoyama T, Horie N, Kato T et al (2000) Helicobacter pylori in oral ulcerations. J Oral Sci 42:225-229

Ship II (1965) Inheritance of aphthous ulcers of the mouth. J Dent Res 44:837-844

Shulman JD (2004) An exploration of point, annual, and lifetime prevalence in characterizing recurrent aphthous stomatitis in USA children and youths. J Oral Pathol Med 33:558-566

Soto Araya M, Rojas Alcayaga G, Esguep A (2004) Association between psychological disorders and the presence of oral lichen planus, burning mouth syndrome and recurrent aphthous stomatitis. Med Oral 9:1-7

Stankiewicz W, Stasiak-Barmuta A (2011) Aging of the immune system. Pol Merkur Lekarski 30:377-379

Subramanyam RV (2011) Occurrence of recurrent aphthous stomatitis only on lining mucosa and its relationship to smoking-a possible hypothesis. Med Hypotheses 77:185-187

Sun A, Rhong-Phong H, Chien-Ts C et al (2001) Some specific human leukocyte antigen (HLA)-DR/DQ haplotypes are more important than individual HLA-DR and -DQ phenotypes for the development of mucocutaneous type of Behçet's disease and for disease shift from recurrent aphthous stomatitis to mucocutaneous type of Behçet's disease. J Oral Pathol Med 30:402-407

Szponar E, Ślebioda Z, Mania-Końsko A (2006) Recurrent aphthous stomatitis in patients attending the Department of Oral Mucosa Diseases of Poznań Medical University-on the basis of 10 years of observation. Czas Stomatol 61:488-494

Tappuni AR, Kovacevic T, Shirlaw PJ et al (2013) Clinical assessment of disease severity in recurrent aphthous stomatitis. J Oral Pathol Med 42:635-641

Tarakji B, Baroudi K, Kharma Y (2012) The effect of dietary habits on the development of the recurrent aphthous stomatitis. Niger Med J 53:9-11
Taş DA, Yakar T, Sakalli H et al (2013) Impact of Helicobacter pylori on the clinical course of recurrent aphthous stomatitis. J Oral Pathol Med 42:89-94

Tuzun B, Wolf R, Tuzun Y, Serdaroglu S (2000) Recurrent aphthous stomatitis and smoking. Int J Dermatol 39:358-360

Vadasz Z, Haj T, Kessel A, Toubi E (2013) Age-related autoimmunity. BMC Med 11:94

Veller-Fomasa C, Gallina P (2006) Recurrent aphthous stomatitis as an expression of pathergy in atopics. Acta Dermatovenerol Alp Panonica Adriat 15:144-147

Victoria JM, Correia-Silva J, Pimenta FJ et al (2005) Serotonin transporter gene polymorphism (5-HTTLPR) in patients with recurrent aphthous stomatitis. J Oral Pathol Med 34:494-497

Volkov I, Rudoy I, Freud T et al (2009) Effectiveness of vitamin B12 in treating recurrent aphthous stomatitis: a randomized, doubleblind, placebo-controlled trial. J Am Board Fam Med 22:9-16

Wang XL, Wang J (2000) Endothelial nitric oxide synthase gene sequence variations and vascular disease. Mol Gen Metab 70:241-251

Wardhana Datau EA (2010) Recurrent aphthous stomatitis caused by food allergy. Acta Med Indones 42:236-240

Wardzyńska A, Kowalski ML (2009) The ageing of the immune system and allergy in elderly. Alergia Astma Immunol 14:239-247

Wilhelmsen NS, Weber R, Miziara ID (2008) The role of immunofluorescence in the pathophysiology and differential diagnosis of recurrent aphthous stomatitis. Braz J Otorhinolaryngol 74: 331-336

Wilhelmsen NS, Weber R, Monteiro F et al (2009) Correlation between histocompatibility antigens and recurrent aphthous stomatitis in the Brazilian population. Braz J Otorhinolaryngol 75:426-431

Williams BD, Lehner T (1977) Immune complexes in Behçet's syndrome and recurrent oral ulceration. Br Med J 1:1387-1389

Wolach B, Gavrieli R, Roos D et al (2012) Lessons learned from phagocytic function studies in a large cohort of patients with recurrent infections. J Clin Immunol 32:454-466

Woo SB, Sonis ST (1996) Recurrent aphthous ulcers: a review of diagnosis and treatment. J Am Dent Assoc 127:1202-1213

Woźniak-Stolarska B, Sajewicz Z, Błachut K (2003) Serum concentration of interleukin-10 in inflammatory bowel disease. Adv Clin Exp Med 12:717-721

Wray D, Graykowsky EA, Notkins AL (1981) Role of mucosal injury in initiating recurrent aphthous stomatitis. $\mathrm{Br}$ Med $\mathrm{J}$ 283: 1569-1570

Yao Q, Furst DE (2008) Autoinflammatory diseases: an update of clinical and genetic aspects. Rheumatology 47:946-951

Yilmaz S, Cimen KA (2010) Familial Behçet's disease. Rheumatol Int 30:1107-1109

Zadik Y, Levin L, Shmuly T et al (2012) Recurrent aphthous stomatitis: stress, trait anger and anxiety of patients. J Calif Dent Assoc 40:879-883 